\title{
Pigments in flower stems of lisianthus under different photoselective shade nets
}

\author{
Julia Martella de Almeida ${ }^{1}$ (D), Cristiane Calaboni ${ }^{1}$ (D), Paulo Hercilio Viegas Rodrigues ${ }^{1^{*}}$ ([) \\ ${ }^{1}$ Universidade de São Paulo "Escola Superior de Agricultura Luiz de Queiroz”, Departamento de Produção Vegetal, \\ Laboratório de Cultura de Tecidos de Plantas Ornamentais, Piracicaba-SP, Brazil.
}

\begin{abstract}
The lisianthus culture is demanded to produce cut flowers and pot vases, grown in a greenhouse using advanced techniques. The present study aimed to evaluate the pigments of different lisianthus cultivars in different photoselective shade nets. The cultivars Flare Deep Rose (pink), Echo Blue BL (purple) and Allemande White BI (white) were cultivated under light-diffusing polyethylene film cover and blue and red color photoselective nets with a shading capacity of $30 \%$, in addition to the control treatment, without the use of the net. The results showed higher values of chlorophyll $b$ and total in the red photoselective net, independent of the cultivar. Leaf colorimetry showed the most intense shade of green was from the cultivar Echo Blue BL. On the other hand, the control showed more intensity, with no significant difference in the leaf green intensity on the blue and red shade nets. In the petals, the cultivar Echo Blue BL showed a more intense blue shade in the red net, however low grade of anthocyanin than in the blue one. In the anthocyanin pigment, this cultivar had lower levels in the treatment of the red net. The results indicate that the use of photoselective shade nets in the culture of lisianthus changes the content of the pigments studied, in varying intensity, depending on the cultivar. Keywords: Eustoma grandiflorum, anthocyanin, floriculture, protected cultivation.
\end{abstract}

\section{Resumo}

Pigmentos em hastes florais de lisianthus sob diferentes telas foto seletivas.

O cultivo do lisianthus destaca-se na cadeia produtiva da floricultura como uma espécie destinada à produção de flores de corte $\mathrm{e}$ em vaso, cultivada em casa de vegetação empregando técnicas avançadas de produção. O objetivo do presente trabalho foi avaliar os pigmentos vegetais de diferentes cultivares de lisianthus sob diferentes telas foto seletivas. As cultivares Flare Deep Rose (rosa), Echo Blue BL (roxa) e Allemande White BI (branca) foram cultivadas com cobertura de filme de polietileno difusor de luz e telas foto seletivas das colorações, azul e vermelha, com capacidade de sombreamento de $30 \%$, além do tratamento controle, sem o uso de tela. Os resultados obtidos demonstraram maiores valores de clorofila $b$ e total em tela foto seletiva vermelha, independentemente do cultivar. Na colorimetria das folhas, a tonalidade de verde mais intensa foi do cultivar Echo Blue BL. Por outro lado, o controle apresentou tonalidade mais intensa, não ocorrendo diferença significativa na intensidade do verde das folhas nas telas azul e vermelha. No telado vermelho, as pétalas da variedade Echo Blue BL apresentaram tonalidade de azul mais intensa, porém menores teores de antocianina. Os resultados indicam que o uso de telas foto seletivas na cultura de lisianthus altera o teor dos pigmentos estudados, em intensidade variável, dependendo do cultivar.

Palavras-chave: Eustoma grandiflorum, antocianina, floricultura, cultivo protegido.

\section{Introduction}

Lisianthus (Eustoma grandiflorum) is a species belonging to the Gentianaceae family and originates from northern Mexico and the Southeast United States. Its flowers have different shapes and colors, which look like rose petals, are appreciated and sold worldwide. Thus, the worldwide demand for lisianthus has been increasing over the last three decades. In Brazil, the economic interest in this species began in the 1990s, as either a cut flower or a potted plant. In the year 2018, lisianthus was the sixth most sold cut flower marketed in Brazil, is widely used in floral arrangements (Backes et al., 2006; Aki, 2018).

The concept of photoselective screens was first studied in the Middle East, specifically in Israel, because the average number of sunny days in this region is approximately

https://doi.org/10.1590/2447-536X.v27i4.2389

"Corresponding author: phrviegas@usp.br

Received: May 1st, 2021 | Accepted: Aug 23, 2021 | Available online: Sept 14, 2021

Licensed by CC BY 4.0 (https://creativecommons.org/licenses/by/4.0/)

Area Editor: Ana Maria Mapeli 
270 days/year (Shahak et al., 2008; Zare et al., 2019). The mechanism of colored shades is based on the distinct filtering of sunlight together with the incorporation of chromatic elements during manufacture to provide physical protection of crops by shading. In this way, plant physiological responses can be altered, through photosynthetic and photo-morphological processes, by manipulating the radiation spectrum (Sivakumar et al., 2018; Sampaio et al., 2020). In Brazil, some regions have a similar average number of sunny days to those of the Middle East, such as the Central West and Northeast regions. In addition to high levels of the incident light, high temperatures also contribute to the use of this type of technology in Brazilian horticulture (Pereira et al., 2017).

The use of photoselective shades in ornamental cultures such as marigold (Calendula officinalis L.) and violet (Viola tricolor) has been shown to affect vegetative grown, carotenoid content, and antioxidant activities, with promising results using the red color shade (Zare et al., 2019). In foliage such as Codiaeum variegatum and Aglaonema commutatum, the use of green, yellow, and red color shades has been evaluated, demonstrating that high levels of anthocyanin and carotenoids were obtained using the red color shade (Zare et al., 2020). The ornamental, Costus lasius, a tropical plant grown in pots, the use of a black color shade associated with a dose of $200 \mathrm{mg} \mathrm{L}^{-1}$ of potassium resulted in the greater production of flower buds (Sampaio et al., 2020). Lisianthus for cut flowers, an increase in the length of the stem was observed using the red color shade, while using the blue shade there was a reduction in the diameter of the stem (Almeida et al., 2016).

Plants' cultivation under different light spectra, mainly at $380 \mathrm{~nm}$ (blue spectra) and $670 \mathrm{~nm}$ (red spectra), causes more intense morphological differences due to the response of photosynthetic pigments. The blue spectrum excites chlorophyll into a higher energy state, releasing part of this energy as heat, which the red spectrum does not (Taiz et al., 2017). In addition, plants under these light spectrums can be affected distinctly for each plant species or cultivar (Zare et al., 2020).
The flower's color, in addition to beauty, confers several important biological functions and is of great importance in plant evolution (Narbona et al., 2018). The phenotypic polymorphism in flower pigmentation is manifested by the variation in pigment intensity, which is determined by the concentration of the pigment and the variation in the petal hue (Gao et al., 2016). Anthocyanins are a group of flavonoids that give the colors pink, red, blue and purple seen in flowers. These pigments play an important role in the pollination and dispersion of fruits and seeds, besides, they have an antioxidant capacity that provides protection to plant tissues against biotic and abiotic stresses (Dini et al., 2019).

Flavonoids are synthesized throughout the development of the petals; however, anthocyanins will start to be synthesized and accumulated shortly before the floral opening. In lisianthus, the change in color of the petals occurs before the floral bud opens and after it has attained its final size. Thus, the floral buds remain with a greenish color throughout their entire development; three days before anthesis, the color of the petals begins to change to pink, red, or purple (Davies et al., 1993).

There is not publish research on the relationship between the use of photoselective shades and their effect on the lisianthus plant pigments grown under greenhouse conditions. In the cultivation of lisianthus. Uddin et al. (2001) observed a direct correlation between luminosity intensity and anthocyanin concentrations. A low level of luminosity intensity under $800 \mathrm{~lx}$ during floral anthesis leads to a reduction of $30 \%$ in the concentration of anthocyanins in the petals, with a $40 \%$ reduction in color intensity.

In view of the foregoing, the present study was conducted to evaluate the effect of photoselective shade nets on the vegetable pigments in the cultivation of three lisianthus cultivars, Flare Deep Rose (pink), Echo Blue BL (purple), and Allemande White BI (white).

\section{Material and Methods}

The seedling used were of the Flare Deep Rose (pink), Echo Blue BL (purple), and Allemande White BI (white) cultivars, supplied by the Ball ${ }^{\circledR}$ Company (Figures $1-\mathrm{a}, \mathrm{b}, \mathrm{c}$ ). 


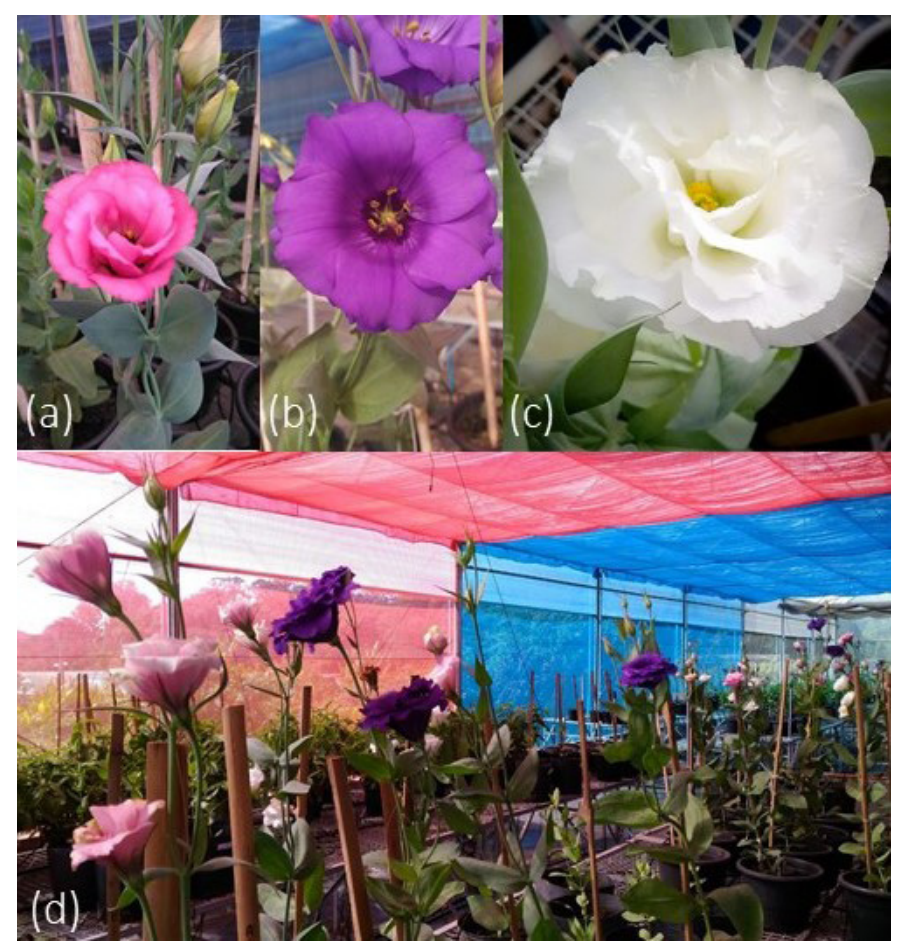

Figure 1. Varieties: Flare Deep Rose (a), Echo Blue BL (b), and Allemande White BI (c). Greenhouse view with photoconvert shade nets (d).

The experiment was conducted in a greenhouse of 6.4 $\mathrm{m}$ width and $36 \mathrm{~m}$ length, north-south orientated, covered with a new polyethylene diffuser film, with $100 \%$ transmissivity. Different photoselective shade nets (Polysak ${ }^{\circledR}$ Plastic Industries Ltd, Negev, Israel) were hung $3.5 \mathrm{~m}$ from the ground, arranged in the color sequence red and blue, with a thickness of $5 \mathrm{~mm}$ and a shading index of $30 \%$ and the control treatment, without the use of the shade nets. The photoselective shades were covered during the experiment and to avoid interference between treatments, the plants were placed in the geometric center of each area, thus avoiding direct interference of the light from one treatment onto another. The greenhousess east side, of each experimental block, were shaded with the corresponding color shade from ground level up to avoid any influence from the incident light during the hours shortly after sunrise (Figures $1-d)$. The greenhouse photosynthetically active radiation (PAR) data was measured (LI-COR LI-200 Pyranometer), the same way monthly temperatures (as well as the minimum and maximum) during the experimental period were measured with the air temperature sensor 1400-101 and data logger (Sutron Xlite 9210) (Table 1).

Table 1. Average (minimum and maximum) temperatures $\left({ }^{\circ} \mathrm{C}\right)$, and minimum and maximum temperatures $\left({ }^{\circ} \mathrm{C}\right)$ under different treatments and periods of cultivation (March/June-2016).

\begin{tabular}{|c|c|c|c|c|c|c|c|c|c|}
\hline & \multicolumn{2}{|c|}{ March/2016 } & \multicolumn{2}{|c|}{ April/2016 } & \multicolumn{2}{c|}{ May/2016 } & \multicolumn{2}{|c|}{ June/2016 } \\
\hline & $\begin{array}{c}\text { Average } \\
\text { Minimum }\end{array}$ & $\begin{array}{c}\text { Average } \\
\text { Maximum }\end{array}$ & $\begin{array}{c}\text { Average } \\
\text { Minimum }\end{array}$ & $\begin{array}{c}\text { Average } \\
\text { Maximum }\end{array}$ & $\begin{array}{c}\text { Average } \\
\text { Minimum }\end{array}$ & $\begin{array}{c}\text { Average } \\
\text { Maximum }\end{array}$ & $\begin{array}{c}\text { Average } \\
\text { Minimum }\end{array}$ & $\begin{array}{c}\text { Average } \\
\text { Maximum }\end{array}$ \\
\hline Red & 20.2 & 40.8 & 16.6 & 38.6 & 14.2 & 31.9 & 9.9 & 28.8 \\
\hline Blue & 19.8 & 39.9 & 16.5 & 38.5 & 13.8 & 31.4 & 10.2 & 27.3 \\
\hline Control & 19.0 & 40.5 & 16.3 & 38.6 & 13.6 & 32.4 & 9.5 & 31.6 \\
\hline & Minimum & Maximum & Minimum & Maximum & Minimum & Maximum & Minimum & Maximum \\
\hline Red & 17.5 & 44.3 & 11.4 & 42.8 & 10.1 & 37.5 & 8.2 & 34.8 \\
\hline Blue & 16.9 & 42.7 & 10.1 & 42.1 & 9.6 & 36.8 & 7.9 & 31.1 \\
\hline Control & 14.3 & 46.2 & 7.2 & 42.7 & 6.7 & 40.2 & 5.2 & 36.6 \\
\hline
\end{tabular}

The seedlings were transplanted into pot-plant $(14.0$ $\mathrm{cm}$ height $\mathrm{x} 16.5 \mathrm{~cm} \varnothing-2.2 \mathrm{~L})$ containing BASE ${ }^{\circledR}$ horticulture substrate (vermiculite, pinus peel, peat moss, coal), irrigated daily using a drip $\left(100 \mathrm{~mL} \mathrm{pot}^{-1}\right)$ and fertigation system daily, as recommended for lisianthus cultivation (SAKATA, 2021). The fertigation consists of the application of $25 \mathrm{~g}$ of calcinit (commercial preparation of soluble calcium nitrate) at planting and from the second week on- 
wards, ten applications of Calcium + Urea (12.5 g Calcium + $5.5 \mathrm{~g}$ Urea) and Mono Ammonium Phosphate (MAP) + Potassium Nitrate + Magnesium Sulfate (3.5 g MAP + 10 g Potassium +7.5 g Magnesium), one application every two weeks.

The colorimetric assays, chlorophyll and anthocyanin analyses were performed using leaves and petals immediately collected from commercial stems 65-70 days after planted (Veiling Holambra, 2020). For quantification of $a$, $b$ and total chlorophyll and carotenoids, the methodology described by Lichtenthaler (1987) was used, with readouts in a Biochrom spectrophotometer (Libra S22): 663 $\mathrm{nm}$ for chlorophyll $a, 646 \mathrm{~nm}$ for chlorophyll $b$, and 470 $\mathrm{nm}$ for carotenoids. Anthocyanin was quantified following the methodology of Lee and Francis (1972), using samples previously frozen in liquid nitrogen, ground and weighed, with $2.0 \mathrm{~g}$ of petals for the purple flower cultivar and 10 $\mathrm{g}$ for the pink flower cultivar being used for determining absorbance at $535 \mathrm{~nm}$. The total anthocyanin content was expressed in milligrams per $100 \mathrm{~g}$ petals.

For direct colorimetric analyses of the petals and leaves, readings were taken using a Minolta ${ }^{\circledR}$ Model CR-400 Colorimeter. For analysis of the petals, three petals per flower (fully open) were used and two readings were taken on the adaxial surface of each petal. For the leaves, three leaves per stem were used (third, fourth and fifth - apex to the base), with three readings taken from the adaxial surface of each leaf. The results were calculated, based on the parameters $\mathrm{L}^{*}, \mathrm{a}^{*}, \mathrm{~b}^{*}$ and expressed in Luminosity (interval between the light and dark), Hue angle (tonality color), and Chromaticity (color intensity).

The experimental design was entirely randomized with a $3 \times 3$ factorial scheme ( 3 covers $\times 3$ cultivars). The experimental units being the stem pot $^{-1}, 3$ replicates, thus using 8 pots of each replicate for cultivar per treatment totaling 216 pots. The data obtained were submitted to $F$ test of the Analysis of Variance. When interaction among the variables was found, we proceeded with comparing the mean values of the treatments by the Tukey test $(p<0.05)$.

\section{Results and Discussion}

The chlorophyll $a$ and $b$, and Total and carotenoids levels presented significant differences for the treatment red shade net, also a significant interaction was observed between the cultivars and the shade net used (Table 2). The purple cultivar showed a significant difference when compared to the control only in total chlorophyll.

Table 2. Contents of Chlorophyll $a, b$, total, and carotenoids (mg/100g) of each cultivar of lisianthus and within each treatment of shade net.

\begin{tabular}{|c|c|c|c|c|c|c|c|c|c|c|c|c|}
\hline \multirow{3}{*}{ Cultivar } & \multicolumn{3}{|c|}{ Chlorophyll a } & \multicolumn{3}{|c|}{ Chlorophyll b } & \multicolumn{3}{|c|}{ Chlorophyll total } & \multicolumn{3}{|c|}{ Carotenoids } \\
\hline & \multicolumn{3}{|c|}{ Shade nets } & \multicolumn{3}{|c|}{ Shade nets } & \multicolumn{3}{|c|}{ Shade nets } & \multicolumn{3}{|c|}{ Shade nets } \\
\hline & Red & Blue & Control & Red & Blue & Control & Red & Blue & Control & Red & Blue & Control \\
\hline Pink & $\begin{array}{c}13.00 \\
\mathrm{aA}\end{array}$ & $\begin{array}{c}9.02 \\
b B\end{array}$ & $\begin{array}{c}8.31 \\
\mathrm{cB}\end{array}$ & $\begin{array}{c}6.23 \\
\mathrm{aA}\end{array}$ & $\begin{array}{c}3.68 \\
b B\end{array}$ & $\begin{array}{c}3.46 \\
b B\end{array}$ & $\begin{array}{c}19.24 \\
\mathrm{aA}\end{array}$ & $\begin{array}{c}12.71 \\
b B\end{array}$ & $\begin{array}{c}11.78 \\
\mathrm{cB}\end{array}$ & $\begin{array}{c}4.12 \\
\mathrm{aA}\end{array}$ & $\begin{array}{c}2.65 \\
b B\end{array}$ & $\begin{array}{c}2.80 \\
b B\end{array}$ \\
\hline White & $\begin{array}{c}11.64 \\
\mathrm{bA}\end{array}$ & $\begin{array}{c}8.75 \\
b B\end{array}$ & $\begin{array}{c}10.97 \\
\text { bA }\end{array}$ & $\begin{array}{c}5.32 \\
\text { bA }\end{array}$ & $\begin{array}{c}3.60 \\
b C\end{array}$ & $\begin{array}{c}4.75 \\
\mathrm{aB}\end{array}$ & $\begin{array}{c}16.67 \\
\text { bA }\end{array}$ & $\begin{array}{c}12.35 \\
b B\end{array}$ & $\begin{array}{c}15.73 \\
\text { bA }\end{array}$ & $\begin{array}{c}3.71 \\
b A\end{array}$ & $\begin{array}{c}2.53 \\
b B\end{array}$ & $\begin{array}{c}3.58 \\
\mathrm{aA}\end{array}$ \\
\hline Purple & $\begin{array}{c}12.95 \\
\text { aA }\end{array}$ & $\begin{array}{c}12.50 \\
\mathrm{aA}\end{array}$ & $\begin{array}{c}12.17 \\
\mathrm{aA}\end{array}$ & $\begin{array}{c}5.92 \\
\text { aA }\end{array}$ & $\begin{array}{l}5.48 \\
\text { aAB }\end{array}$ & $\begin{array}{c}5.21 \\
\mathrm{aB}\end{array}$ & $\begin{array}{c}18.88 \\
\mathrm{aA}\end{array}$ & $\begin{array}{c}17.99 \\
\mathrm{aAB}\end{array}$ & $\begin{array}{c}17.30 \\
\mathrm{aC}\end{array}$ & $\begin{array}{l}3.94 \\
\text { abA }\end{array}$ & $\begin{array}{c}3.78 \\
\mathrm{aA}\end{array}$ & $\begin{array}{c}3.72 \\
\mathrm{aA}\end{array}$ \\
\hline HSD & \multicolumn{3}{|c|}{0.983} & \multicolumn{3}{|c|}{0.489} & \multicolumn{3}{|c|}{1.452} & \multicolumn{3}{|c|}{0.338} \\
\hline
\end{tabular}

Pink (lisianthus cv. Flare Deep Rose), white (lisianthus cv. Allemande White BI) and purple (lisianthus cv. Echo Blue BL).

Treatments followed by different lowercase letters in the column differ at the $5 \%$ level.

Treatments followed by different capital letters in the line differ at the Tukey test, $5 \%$ level

The purple and pink cultivars differed from the white in all the variables analyzed, showing higher values of chlorophyll $a$ and $b$, total chlorophyll, and carotenoids in the treatment with the red shade net. Within the pink cultivar, the control shade net demonstrated the lowest chlorophyll and carotenoids levels of all the shades. On the other hand, in the white cultivar, the blue shade net presented the lowest all pigments production, when compared to the other treatments.

The plant adaptation to the greenhouse light spectrum conditions is related to the plant's photosynthetic efficiency. These physiological responses will result in overall plant development, including flower production, as the increase in petal carbohydrates results in cell expansion that induces flowering (Almeida et al., 2004; Norikoshi et al., 2016). Also, carbohydrates are the main energy source of plants, and they need an adequate amount of carbohydrates to flourish (Taiz et al., 2017).

These results differed from those of Lima et al (2010) when studied Anthurium, cultivated under blue, red, and black shade nets and a thermo-reflective shade net, they observed that the highest content values of total chlorophyll and chlorophyll $a$ and $b$ were obtained in plants cultivated under the black shade net, followed by plants cultivated under a thermo-reflective shade net, and lastly, those under the red and blue shade nets. Oren-Shamir et al. (2001), studying Pittosporum variegatum plants cultivated under gray, black, and thermo-reflective shade nets; 
and blue, red, and green photoselective shade nets, observed that they presented no significant differences in the chlorophyll content values. However, Souza et al. (2013) in the cultivation of Mentha piperita obtained higher concentrations of chlorophyll $b$ in the plants cultivated under red and blue shade nets compared to those cultivated under full sunlight.

Photoselective shade nets realize benefits during greenhouse cultivate, however, it must consider that effect on the plant physiology can vary according to species and even cultivars (Costa et al., 2019).

All the colorimetric variables of the lisianthus flower petals analyzed (Table 3 ), presented significant differences between the three distinct cultivars of lisianthus, responsible for a different petal color (pink, white and purple). For the variable $\left(b^{*}\right)$ tone/hue, significant interactions were observed between the varieties and the shade nets used (Table 3).

Table 3. Luminosity variables $\left(\mathrm{L}^{*}\right)$, red/green coordinates $\left(\mathrm{a}^{*}\right)$, yellow/blue $\left(\mathrm{b}^{*}\right)$ coordinates, hue angle hue, and color purity (chroma) of the petals and leaves of each lisianthus cultivar and within each shade net.

\begin{tabular}{|c|c|c|c|c|c|}
\hline & \multicolumn{5}{|c|}{ Petals } \\
\hline & $\mathbf{L}^{*}$ & $a^{*}$ & $\mathbf{b}^{*}$ & Chroma & Hue \\
\hline \multicolumn{6}{|l|}{ Cultivar } \\
\hline Pink & $61.83 \mathrm{a}$ & $21.94 \mathrm{~b}$ & 2.82 & $22.16 \mathrm{~b}$ & $0.13 \mathrm{c}$ \\
\hline White & $86.01 \mathrm{c}$ & $-5.19 c$ & 7.90 & $9.41 \mathrm{c}$ & $-0.98 \mathrm{a}$ \\
\hline Purple & $26.89 \mathrm{~b}$ & $34.86 \mathrm{a}$ & -27.98 & $44.79 \mathrm{a}$ & $-0.68 b$ \\
\hline \multicolumn{6}{|l|}{ Shade Net } \\
\hline Red & $57.39 \mathrm{~b}$ & $18.10^{\text {ns }}$ & -5.87 & $26.33^{\text {ns }}$ & $-0.51^{\mathrm{ns}}$ \\
\hline Blue & $57.93 \mathrm{ab}$ & $16.93^{\mathrm{ns}}$ & -5.52 & $24.66^{\mathrm{ns}}$ & $-0.50^{\text {ns }}$ \\
\hline Controle & $59.370 \mathrm{a}$ & $16.57^{\mathrm{ns}}$ & -5.84 & $25.37^{\mathrm{ns}}$ & $-0.52^{\mathrm{ns}}$ \\
\hline \multicolumn{6}{|l|}{ Test F } \\
\hline Cultivar (C) & $2704.57 * *$ & $777.86^{* *}$ & $5728.07 * *$ & $894.79 * *$ & $1669.87 * *$ \\
\hline Shade Net(T) & $3.15^{\mathrm{ns}}$ & $1.19^{\text {ns }}$ & $0.57^{\mathrm{ns}}$ & $1.95^{\mathrm{ns}}$ & $0.70^{\text {ns }}$ \\
\hline CxT & $0.77^{\mathrm{ns}}$ & $0.68^{\mathrm{ns}}$ & $3.12 *$ & $0.44^{\mathrm{ns}}$ & $2.06^{\mathrm{ns}}$ \\
\hline CV & 4.81 & 20.86 & 21.87 & 11.53 & 13.58 \\
\hline \multirow[t]{3}{*}{ HSD } & 1.94 & 2.487 & 0.874 & 2.033 & 0.048 \\
\hline & \multicolumn{5}{|c|}{ Leaves } \\
\hline & $\mathbf{L}^{*}$ & $a^{*}$ & $\mathbf{b}^{*}$ & Chroma & Hue \\
\hline \multicolumn{6}{|l|}{ Cultivar } \\
\hline Pink & 45.50 & $-13.54 b$ & $17.38 \mathrm{~b}$ & $22.08 \mathrm{~b}$ & $-0.90 \mathrm{a}$ \\
\hline White & 45.63 & $-13.60 \mathrm{~b}$ & $17.62 \mathrm{~b}$ & $22.20 \mathrm{~b}$ & $-0.91 \mathrm{a}$ \\
\hline Purple & 46.07 & $-14.78 \mathrm{a}$ & $19.18 \mathrm{a}$ & $24.12 \mathrm{a}$ & $-0.91 \mathrm{a}$ \\
\hline \multicolumn{6}{|l|}{ Shade Net } \\
\hline Red & 45.38 & $-13.78 b$ & $17.73^{\text {ns }}$ & $22.50^{\mathrm{ns}}$ & $-0.90^{\mathrm{ns}}$ \\
\hline Blue & 44.98 & $-13.69 b$ & $17.99^{\mathrm{ns}}$ & $22.45^{\mathrm{ns}}$ & $-0.91 \mathrm{~ns}$ \\
\hline Controle & 46.84 & $-14.45 \mathrm{a}$ & $18.46^{\mathrm{ns}}$ & $23.45^{\mathrm{ns}}$ & $-0.90^{\mathrm{ns}}$ \\
\hline \multicolumn{6}{|l|}{ Test $F$} \\
\hline Cultivar (C) & 0.55 & $13.63^{* *}$ & $7.24 * *$ & $7.75^{* *}$ & $0.22^{\mathrm{ns}}$ \\
\hline Shade Net(T) & 6.03 & $4.81^{*}$ & $1.03^{\mathrm{ns}}$ & $1.89^{\mathrm{ns}}$ & $1.94^{\mathrm{ns}}$ \\
\hline CxT & 4.64 & $0.56^{\mathrm{ns}}$ & $0.76^{\mathrm{ns}}$ & $0.60^{\mathrm{ns}}$ & $0.82^{\text {ns }}$ \\
\hline CV & 4.27 & 6.65 & 9.86 & 8.83 & 2.77 \\
\hline HSD & 1.35 & 0.64 & 1.23 & 1.39 & 0.01 \\
\hline
\end{tabular}

Pink (lisianthus cv. Flare Deep Rose), white (lisianthus cv. Allemande White BI) and purple (lisianthus cv. Echo Blue BL).

Treatments followed by different letters in the column differ at the level of $5 \%$;

$*$ Difference of $5 \%$ of probability $(p<0.05)$

** Difference of $1 \%$ of probability $(p<0.01)$;

ns Not significant at the Tukey test, $5 \%$ probability level $(p>0.05)$ 
There is an interaction between flower cultivars and shade nets for the variable $b^{*}$, only observed in the purple flower cultivar. The control treatment and the red shade net produced flowers with a bluer hue when compared to the treatment with the blue color shade. Thus, light quality and intensity can affect the hue of the flower color. Anthocyanidins are molecules without bound sugars (aglycones) that provide the basis of floral pigmentation. All anthocyanin pigments are derived from one of the three aglycones: cyanidin, delphinidin, and pelargonidin (Khoo et al., 2017; Chaves-Silva et al., 2018). Flowers with the same types and concentration of anthocyanidins may have different color intensities (Figueiredo et al., 1999), depending on the concentration of co-pigments, vacuolar $\mathrm{pH}$, and the light intensity (Passeri et al., 2016; Gu et al., 2019). Anthocyanins are very reactive to light intensity (Trojak and Skowron,
2017; Zhang et al., 2019). In the present study, the average light intensity using the red color shade was 291 $\mu \mathrm{mol} \mathrm{m} \mathrm{m}^{-2} \mathrm{~s}^{-1}$ while a value of $582 \mu \mathrm{mol} \mathrm{m}^{-2} \mathrm{~s}^{-1}$ was measured in the control treatment. These results showed that in the purple cultivar of lisianthus, the light intensity did not affect $b^{*}$, but the light quality did.

Analyzing colorimetric variables on leaves (Table 4), in comparison to the control treatment, significant differences were observed in the variable $\mathrm{L}^{*}$ and $\mathrm{a}^{*}$, in comparison with the other shade nets, resulting in plants with leaves of lighter green tone/hue. The leaves of the purple flower cultivar under the control treatment presented a more intense green color when compared with the other cultivars that presented lower a* values. With regards to the variable $b^{*}$, the pink and white flower cultivars differed from the purple flower cultivar, because they presented leaves with a slightly bluish tone/hue.

Table 4. Means of the variable yellow/blue $\left(b^{*}\right)$ in petals, luminosity variables $\left(L^{*}\right)$ in leaves and petals anthocyanin within each lisianthus cultivar, and each shade net.

\begin{tabular}{|c|c|c|c|c|}
\hline \multicolumn{5}{|c|}{ Colorimetry Petals-b* } \\
\hline \multirow{2}{*}{ Cultivar } & \multicolumn{3}{|c|}{ Shade Nets } & \\
\hline & Red & Blue & Controle & \\
\hline Pink & $2.65 \mathrm{cA}$ & $2.66 \mathrm{cA}$ & $3.17 \mathrm{cA}$ & \\
\hline White & $8.01 \mathrm{bA}$ & $7.55 \mathrm{bA}$ & $8.16 \mathrm{bA}$ & \\
\hline Purple & $28.29 \mathrm{aAB}$ & $26.78 \mathrm{aB}$ & $28.87 \mathrm{aA}$ & \\
\hline HSD & 1.50 & 1.50 & 1.50 & \\
\hline \multicolumn{5}{|c|}{ Colorimetry Leaves- $L *$} \\
\hline \multirow{2}{*}{ Cultivar } & \multicolumn{3}{|c|}{ Shade Nets } & \\
\hline & Red & Blue & Controle & \\
\hline Pink & $45.73 \mathrm{aA}$ & $46.09 \mathrm{aA}$ & $44.70 \mathrm{bA}$ & \\
\hline White & $44.88 \mathrm{aB}$ & $44.45 \mathrm{aB}$ & $47.55 \mathrm{aA}$ & \\
\hline Purple & $45.54 \mathrm{aB}$ & $44.40 \mathrm{aB}$ & $48.28 \mathrm{aA}$ & \\
\hline HSD & 2.34 & 2.34 & 2.34 & \\
\hline \multicolumn{5}{|c|}{ Anthocyanins Petals (mg/100g) } \\
\hline \multirow{2}{*}{ Cultivar } & \multicolumn{3}{|c|}{ Shade Nets } & HSD \\
\hline & Red & Blue & Controle & \\
\hline Pink & $4.00 \mathrm{bA}$ & $3.33 \mathrm{bA}$ & $3.66 \mathrm{bA}$ & 2.71 \\
\hline Purple & $24.33 \mathrm{aB}$ & $28.00 \mathrm{aA}$ & $28.66 \mathrm{aA}$ & 2.71 \\
\hline HSD & 2.18 & 2.18 & 2.18 & \\
\hline
\end{tabular}

Pink (lisianthus cv. Flare Deep Rose), white (lisianthus cv. Allemande White BI) and purple (lisianthus cv. Echo Blue BL).

Treatments followed by different lowercase letters in the column differ at the $5 \%$ level.

Treatments followed by different capital letters in the line differ at the Tukey test, $5 \%$ level.

Significant interaction occurred between the cultivars and the type of covering to produce the variable luminosity (L). The control treatment presented leaves with a lighter tone/hue of green when compared to those under the nets, except the pink cultivar, which presented higher $\mathrm{L}$ values (Table 3). On the floral stem, in addition to flowers, the leaves may present different tones/hues, which represent a complement to ornamentation perception. The possibility of controlling the shade or intensity of leaf color increases the options available to the floriculture sector.

For anthocyanin content (Table 4), preliminary analyses demonstrated that in the white flower cultivar minimal or no anthocyanins were detected, therefore, only the cultivars with purplish-red color in the petals were analyzed, 
namely the cultivars with purple and pink flowers. The two cultivars showed differences due to their characteristic colors. Thus, the darker the flower color, the higher the anthocyanin concentration, therefore the highest contents were observed in the purple flower.

In the cultivar with pink flowers, no significant difference was observed in anthocyanin levels between the shade nets. However, in the cultivar with purple flowers, the anthocyanin level under the red shade net was significantly less than under the blue shade net and the control, with no significant difference observed between the latter two treatments (Table 4). Blue spectrum promoted anthocyanin accumulation in petunia petals, as well as a white spectrum, while red spectrum blocked biosynthesis. According to the authors, the results suggest that the blue spectrum is a key factor for anthocyanins biosynthesis and accumulation $(\mathrm{Fu}$ et al., 2020).

In contrast, when evaluating the effect of the different photoselective shade nets (yellow, red, and green) on ornamental species of marigold (Calendula officinalis L.) and violet (Viola tricolor), Zare et al. (2019) observed an increment in the concentration of anthocyanins for the Violet under the green and red shade nets, but no significant effect of the photoselective shade nets was observed for Marigold. For the lisianthus species, Meir et al. (2010) evaluated the expression of anthocyanin biosynthesis genes under varying light conditions. When comparing normal (greenhouse) and low light culture conditions $\left(14 \mu \mathrm{mols} \mathrm{m}^{2} \mathrm{~s}^{-1}\right)$, for lisianthus cultivars 'Eco blue' and 'Eco balboa', the authors observed lower intensity pigmentation in flowers cultivated under the low light conditions. Additionally, under low light conditions, the expression of anthocyanin genes was significantly reduced. In the present study, under low light intensity $\left(291 \mu \mathrm{mol} \mathrm{m} \mathrm{m}^{-2} \mathrm{~s}^{-1}\right)$ and the red shade net, the biosynthesis of anthocyanins in the purple flower cultivar was decreased compared with the control $\left(582 \mu \mathrm{mol} \mathrm{m} \mathrm{m}^{-2}\right.$ $\mathrm{s}^{-1}$ ). On the other hand, at an even lower light intensity (206 $\mu \mathrm{mol} \mathrm{m} \mathrm{m}^{-2} \mathrm{~s}^{-1}$ ), the same cultivar under the blue shade net presented anthocyanin levels similar to the control. This result suggested the light quality affects the anthocyanin content for the lisianthus purple cultivar.

The average temperature during flower cultivation is one of the environmental factors that most affect the anthocyanin concentration in plant tissues (Kim et al., 2017). High temperatures reduce anthocyanin concentration, while at low temperatures, the concentration increases (Nakatsuka et al., 2019). In our study, the Ball ${ }^{\circledR}$ Company's recommendation for the lisianthus cultivars was appropriate for the Brazilian autumn and so that the typical autumn temperatures (Table 1) should have little or no influence on the study of pigment production.

In the commercial production of flowers, the color and tonalities change every year and depend on the tendencies of fashion and designers. These variations in tone/hue and intensity of color in the cut flowers provoked by light quality and intensity may be used by producers as a tool to obtain differentiated products in the cut flower market.

\section{Conclusions}

The results showed that the photoselective shade nets alter the vegetable pigments of the lisianthus culture. This is the first report on the effect of photoselective shade nets on pigments lisianthus culture. Further studies on postharvest and the quality of the lisianthus flower grown in photoselective shade nets must be carried out, until the effective use of this technique.

\section{Acknowledgments}

The authors thank CAPES for granting the first author's scholarship. FAPESP (2015/14192-4) to financial support.

\section{Author contribution}

All authors contributed the same way to prepare this article.

\section{References}

ABBASNIA ZARE, S.K.; SEDAGHATHOOR, S.; PADASHT DAHKAEI, M.N.; HASHEMABADI, D. The effect of different colored netting on quantitative and qualitative traits of two foliage plant species (Codiaeum variegatum and Aglaonema commutatum). Advances in Horticultural Science, v.34, n.1, p.25-33, 2020. https:// doi.org/10.13128/ahsc-8253

AKI, A. 2018. Ranking das flores mais vendidas no Brasil. Available at: <https://www.negocioscomflores.com.br/ artigos-gratis/ranking-das-flores-mais-vendidas-no-brasil/> Accessed on December 3th 2020.

ALMEIDA, J.M.; CALABONI, C.; RODRIGUES, P.H.V. Lisianthus cultivation using differentiated light transmission nets. Ornamental Horticulture, v.22, p.143-146. 2016. 10.14295/oh.v22i2.905

ALMEIDA, L.P.; ALVARENGA, A.A.; CASTRO, E.M.; ZANELA, S.M.; VIEIRA, C.V. Crescimento inicial de plantas de Cryptocaria aschersoniana Mez. submetidas a níveis de radiação solar. Ciência Rural, v.34, n.1, p.83-88, 2004.

BACKES, F.A.A.L.; BARBOSA, J.G.; SEDIYAMA, M.A.N.; MARTINEZ, H.E.P.; CECON, P. R.; BARBOSA, M.S. Produção de lisianto cultivado em vasos com diferentes soluções nutritivas e formas de condução. Horticultura Brasileira, v.24, p.6-10, 2006. 10.1590/S010205362006000100002

CHAVES-SILVA, S.; SANTOS, A.L.; CHALFUN JÚNIOR, A.; ZHAO, J.; PERES, L.E.P.; BENEDITO, V.A. Understanding the genetic regulation of anthocyanin biosynthesis in plants - Tools for breeding purple varieties of fruits and vegetables. Phytochemistry, v.153, p.11-27, 2018. http://doi.org/10.106/j.phytochem.2018.05.013 
COSTA, A.F.; CARNEIRO, K.S.; ANDRADE, H.M.; UCHOA, K.S.A. Efeito da qualidade de luz no desenvolvimento da moringa sob telados de diferentes cores em clima semiárido. Revista Internacional de Ciências, v.9, n.2, p.103-114, 2019. 10.12957/ric.2019.39244

DAVIES，K.M.; BRADLEY， J.M.; SCHWINN, K.E.; MARKHAM, K.R.; PODIVINSKY, E. Flavonoid biosynthesis in flower petals of five lines of lisianthus (Eustoma grandiflorum Grise). Plant Science, v.95, p.67-77, 1993. 10.1016/0168-9452(93)90080-j

DINI, C.; ZARO, M.J.; VIÑA, S.Z. Bioactivity and functionality of anthocyanins: a review. Current Bioactivity Compounds, v.15, n.5, p.507-523, 2019. https://doi.org/10 $.2174 / 1573407214666180821115312$

FIGUEIREDO, P.; GEORGE, F.; TATSUZAWA, F.; TOKE, K.; SAITO, N.; BROUILLARD, R. New features of intramolecular co-pigmentation by acylated anthocyanins. Phytochemistry, v.51, p.125-132, 1999. https://doi. org/10.1016/S0031-9422(98)00685-2

FU, Z.; SHANG, H.; JIANG, H.; GAO, J.; DONG, X.; WANG, H.; LI, Y.; WANG, L.; ZHANG, J.; SHU, Q.; CHAO, Y.; XU, M.; WANG, R.; WANG, L.; ZHANG, H. Systematic identification of the light-quality responding anthocyanin synthesis-related transcript in petunia petals. Horticultural Plant Journal, v.6, n.6, p.428-438, 2020. https://doi.org/10.1016/j.hpj.2020.11.006

GAO, L.; YANG, H.; LIU, H.; YANG, J.; HU, Y. Extensive transcriptome changes underlying the flower color intensity variation in Paeonia ostii. Frontiers Plant Science, v.6, p.1205, 2016. 10.3389/fpls.2015.01205

GU, K.; WANG, C.; HU, D.; HAO, Y. How do anthocyanins paint our horticultural products? Scientia Horticulturae, v.249, p.257-262, 2019. https://doi.org/10.1016/j. scientia.2019.01.034

KIM, S.; HWANG, G.; LEE, S.; ZHU, J.; PAIK, I.; NGUYEN, T.T.; KIM, J.; OH, E. High ambient temperature represses anthocyanin biosynthesis through degradation of HYS. Frontiers in Plant Science, v.8, p.1787, 2017. https://doi.org/10.3389/fpls.2017.01787

KHOO, H.E.; AZLAN, A.; TANG, S.T.; LIM, S.M. Anthocyanidins and anthocyanins: colored pigments as food, pharmaceutical ingredients, and the potential health benefits. Food \& Nutrition Research, v.61, n.1, p.1361779, 2017. https://doi.org/10.1080/16546628.2017.1361779

LEE, D.H.; FRANCIS, F.J. Standardization of pigment analysis in cranberries. HortScience, v.7, n.1, p. 83-84, 1972.
LICHTENTHALER, H.K. Chlorophylls, and carotenoids: pigments of photosynthetic biomembranes. Methods in Enzymology, v.148, n.22, p.350-382, 1987.

LIMA, J.D.; NOMURA, E.S.; FUZITANI, E.J.; SILVA, S.H.M.G. Variáveis fisiológicas de antúrio cultivado sob diferentes malhas de sombreamento. Scientia Agraria, v.11, n.3, p. 193-200, 2010. http://dx.doi.org/10.5380/rsa. v11i3

MEIR, S.; KOCHANEK, B.; WEISS, D.; GLICK, A.; SALIM, S.; LERS, A.; BURD, S.; PHILOSOPH-HADAS, S. Reduced petal pigmentation in lisianthus (Eustoma grandiflorum) flowers under low light conditions is associated with decreased Expression of anthocyanin biosynthesis genes. Acta Horticulturae, v.877, p.1735-1744, 2010. 10.17660/ActaHortic.2010.877.238

NARBONA, E., WANG, H.; ORTIZ, P.L.; ARISTA, M.; IMBERT, E. Flower colour polymorphism in the Mediterranean Basin: occurance, maintenance and implications for speciation. Plant Biology, v.20, p.8-20, 2018. 10.1111/ plb. 12575

NAKATSUKA, T.; SUZUKI, T.; HARADA, K.; KOBAYASHI, Y.; DOHRA, H. Floral organ- and temperaturedependent regulation of anthocyanin biosynthesis in Cymbidium hybrid flowers. Plant Science, v.287, p.110173, 2019. https://doi.org/10.1016/j.plantsci.2019.110173

NORIKOSHI, R.; KOHATA, K.; SHIMIZU-YUMOTO, H.; GOTO, R.; ICHIMURA, K. Identification of soluble carbohydrates and subcellular concentration in petals during flower opening in Eustoma grandiflorum. The Japanese Society for Horticultural Science, p.MI-103, 2016. https://doi.org/10.2503/hortj.MI-103

OREN-SHAMIR, M.; GUSSAKOVSKY, E.; EUGENE, E.; NISSIM-LEVI, A.; RATNER, K.; OVADIA, R.; GILLER, Y.; SHAHAK, Y. Colored shade nets can improve the yield and quality of green decorative branches of Pittosporum variegatum. Journal of Horticultural Science and Biotechnology, v.76, n.3, p.353-361, 2001. https://doi.org/10.1080/14620316.2001.11511377

PASSERI, V.; KOES, R.; QUATTROCCHIO, F.M. New challenges for the design of high-value plant products: stabilization of anthocyanins in plant vacuoles. Frontiers in Plant Science, v.7, n.153, 2016. https://doi.org/10.3389/ fpls.2016.00153

PEREIRA, E.B.; MARTINS, F.R.; GONÇALVES, A.R.; COSTA, R.S.; LIMA, F L.; RÜTHER, R.; ABREU, S.L.; TIEPOLO, G.M.; PEREIRA, S.V.; SOUZA, J.G. Atlas brasileiro de energia solar. 2.ed. São José dos Campos: INPE, 2017. http://doi.org/10.34024/978851700089 
SAKATA, 2021. Lisianthus Cut Flowerpot Culture. Available at: <https://sakataornamentals.com/wp-content/ uploads/sites/2/2021/06/LisianthusCutFlowerPotPlantCulture-1016-SAKATA.pdf $>$ Accessed on Dec 15th, 2020.

SAMPAIO, P.R.F.; RODRIGUES, P.H.V.; DUARTE, S.N.; SOUSA NETO, O.N.D.; NASCIMENTO, J.G.; PIEDADE, S.M.S. Photo-selective nets and potassium concentrations on Costus lasius crop. Revista Brasileira de Engenharia Agrícola e Ambiental, v.24, n.3, p.143-148, 2020. https:// doi.org/10.1590/1807-1929/agriambi.v24n3p143-148

SHAHAK, Y.; GAL, E.; OFFIR, Y.; BENYAKIR, D. Photoselective shade netting integrated with greenhouse technologies for improved performance of vegetable and ornamental crops. Acta Horticulturae, v.797, p.7580, 2008. https://doi.org/10.17660/ActaHortic.2008.797.8

SIVAKUMAR, D.; JIFON, J.; SOUNDY, P. Spectral quality of photo-selective shade nettings improves antioxidants and overall quality in selected fresh produce after postharvest storage. PloS one, v.13, n.6, p.e01199628, 2018. https://doi.org/10.1080/87559129.2017.1298124

SOUZA, G.S.; OLIVEIRA, U.C.; SILVA, J.S.; LIMA, J.C. Crescimento, produção de biomassa e aspectos fisiológicos de plantas de Mentha piperita L. cultivadas sob diferentes doses de fósforo e malhas coloridas. Global Science and Technology, v.6, p.35-44, 2013. https://doi.org/10.18677/ EnciBio_201
TAIZ, L.; ZEIGER, E.; MØLLER, I.M.; MURPHY, A. Fisiologia e desenvolvimento vegetal. 6.ed. Porto Alegre: Artmed, 2017. 858p.

TROJAK, M.; SKOWRON, E. Role of Anthocyanins in high-light stress response. World Scientific News, v.81, n.2, p.150-168, 2017.

UDDIN, A.F.M.J; HASHIMOTO, F; KAKETANI, M; SHIMIZU, K; SAKATA, Y. Analysis of light and sucrose potencies on petal coloration and pigmentation of lisianthus cultivars (in vitro). Scientia Horticulturae, v.89, p.73-82. 2001. https://doi.org/10.1016/S0304-4238(01)00224-2

Veiling Holambra, 2020. Padrão de Qualidade. Lisianthus de Corte. Available at: <http://veiling.com.br/uploads/padrao/lisianthus-fc.pdf $>$ Accessed on Dec 15 2020.

ZARE, S.K.A.; SEDAGHATHOOR, S.; DAHKAEI, M.N.P.; HASHEMABADI, D. The effect of light variations by photoselective shade nets on pigments, antioxidant capacity, and growth of two ornamental plant species: Marigold (Calendula officinalis L.) and violet (Viola tricolor). Cogent Food \& Agriculture, v.5, n. 1, 1650415, 2019. https://doi.org/10.1080/23311932.2019.1650415

ZHANG, Y.; LI, Y.; LI, W.; HU, Z.; YU, X.; TU, Y.; ZHANG, M.; HUANG, J.; CHEN, G. Metabolic and molecular analysis of nonuniform anthocyanin pigmentation in tomato fruit under high light. Horticultural research, v.6, n.1, p.1-21, 2019. https://doi.org/10.1038/s41438-019$0138-2$ 